\title{
Is 'WTO-Plus' a Policy Option for India-China Agriculture Trade? A CGE Analysis
}

\author{
Shahid AHMED", Saba ISMAIL ${ }^{* *}$
}

Received: June 21, 2020

Revised: October 11, 2020

Accepted: October 15, 2020.

\begin{abstract}
This paper examines the effect of bilateral tariff reduction in the agriculture sector between India and China. The results are evaluated in terms of welfare, output, employment and the potential trade flows between India and China using the GTAPmodel. The present study suggests that partial tariff reduction on imports of agricultural commodities between India and China may be welfare-enhancing for both India and China while complete tariff reduction on imports of agricultural commodities may have welfare loss for India, though there will be substantial welfare gains for China. The study reveals that welfare gains for China are larger in comparison to India. The study suggests that a well calculated and strategically negotiated tariff reduction in the agriculture sector may create a win-win situation for both partners. The study further argues that China should offer preferential market access to India for mutually beneficial and welfare-enhancing engagements for both countries. Finally, the study concludes that there exists a narrow scope for 'WTO-Plus' approach for India-China agriculture trade relations. India should assess all pros and cons as it has revenue loss and impact on economically marginalised 'Farming Community'.
\end{abstract}

Keywords: Agriculture Sector, Computable General Equilibrium Models, Economic Integration, GTAP Model

JEL Code Classifications: F1, F13, F14, F17

UDC: 339

DOI: https://doi.org/10.17015/ejbe.2020.026.02

\footnotetext{
*Professor, Department of Economics, Jamia Millia Islamia, New Delhi, India. E-mail: sahmed@jmi.ac.in

${ }^{* *}$ Associate Professor, Department of Economics, Jamia Millia Islamia, New Delhi, India. E-mail: sismail@jmi.ac.in
}

Copyright (C), 2020 Ala-Too International University. 


\section{Introduction}

India and China are the two major emerging economies of the world. At present, India and China are 5th and 2nd largest economies of the world, respectively on a nominal basis. Both (the) countries together share $19.46 \%$ and $27.18 \%$ of the total global wealth in nominal and PPP terms, respectively. Among Asian countries, China and India together contribute more than half of Asia's GDP. From the agriculture sector perspective, agriculture contributes $6.4 \%$ of the total world's economic production. In total production, China is the largest contributor, followed by India. China and India account for $19.49 \%$ and $7.39 \%$ of the total global agricultural output, respectively.

In the past few decades, both China and India have gained in multiple dimensions after unlocking their economies. External trade is the backbone of both the economies and a crucial contributor to their high growth over a long period. Export growth occupies a place of strategic importance in the context of economic development which has led to various remarkable changes in their foreign trade policies. In post COVID-19 era, the resurgence and resistance of economies like India and China are expected to give direction to the global economy. With COVID-19, fiscal policies have taken a driving seat to bring back the economies on the right path. For obvious and emergent reasons, trade policy has taken a back seat or became irrelevant in an immediate short period. However, government actors need to finetune their trade policies for medium to long run revival and sustaining economic growth.

Agriculture is the most important sector of Indian Economy. The Indian agriculture sector accounts for $16.5 \%$ of India's gross domestic product (GDP) while employs $43.21 \%$ of the countries workforce. Though the share of India's workforce in the agriculture sector is declining, it is still the main sector of employment. India is the world's largest producer of milk, pulses and jute, and the second-largest producer of rice, wheat, sugarcane, groundnut, vegetables, fruit, and cotton. It is also one of the leading producers of spices, fish, poultry, livestock, and plantation crops. In China, the agriculture sector had contributed about 7.1\% to the GDP while employing $26.1 \%$ of the countries' workforce. China is the world's largest producer of a number of crops including rice, wheat, potatoes, tomato, sorghum, peanuts, tea, millet, barley, oilseed, corn, and soybeans, apples, pears and cotton. Total vegetable production represents a staggering $50 \%$ of the world's total output. And, in the fruit sector, China grows $30 \%$ of the global output.

India ranks amongst the top ten exporters of agricultural products in the world. The top exports comprise of sugar, beef, rice and shrimp. Indian agricultural exports grew at 9 per cent compared to China (8\%), Brazil (5.4\%) and the U.S. (5.1\%) between 2007 and 2016. During this period, exports of coffee, cereals, horticultural produce doubled; while exports of meat, fish and processed products grew between three to five times. Yet, India has remained at the lower end of the global agriculture export 
value chain given that majority of its exports are low value, raw or semi-processed. India's high value and value-added agriculture produce in its agriculture export basket is less than $15 \%$ compared to $25 \%$ in the U.S. and $49 \%$ in China (ICFA, 2019). While China is considered a major global exporter of horticulture products. China's agricultural exports are labour-intensive products that have been increasing dramatically, particularly after its 2001 accession to the World Trade Organization (USITC, 2011). China is currently the fifth largest exporter and the fourth largest importer of agricultural products in the world. China's substantial increase in fruit and vegetable production was a major factor behind its agricultural export growth (Carter, 2011).

In the year 2018-19, India's total exports of agricultural and allied commodities to China were of the order of USD 1999 million. Major Exports of India were raw cotton, other shrimp and prawn, castor oil, capsicum pimento, etc. In the same year, India's total import of agricultural and allied commodities from China was of the order of USD 282 million. Major exports of China were animal feeding, kidney beans, bamboos, wheat gluten etc. China was looking to boost its agricultural exports to India while increasing imports of rapeseed and soymeal. India's agriculture export policy, 2018 aims to increase India's agricultural exports to USD 60 billion by 2022 and USD 100 billion in the next few years with a stable trade policy regime. In this context, China may be an important export destination.

India and China started its trade negotiation for a Free Trade Agreement, but the agreement is still under negotiation because of the inability to reach consensus on several issues. In June 2003, China and India formed a Joint Study Group (JSG) to expand trade and economic cooperation between them. The JSG was in favour of FTA in its assessment. However, most of the independent researchers have been apprehensive of an FTA in the short run, arguing upon the given differences in China's and India's tariff rates along with some other issues. It is perceived that India will lose much from such an FTA. In fact, there has been considerable opposition to the Regional Comprehensive Economic Partnership (RCEP) in India, which resulted in India's pulling out of the RCEP. Several organisations, especially from the agricultural sector, have opposed India to become a member of this agreement. They were concerned about the RCEP's potential impact on sectors like agriculture, which would affect the country's vast rural population. In this backdrop, the focal objectives of this paper are (i) to examine 'WTO-Plus' scenario in case of agricultural tariff liberalisation and its impact on welfare, output, employment and trade in prospective India-China FTA; and (ii) to suggest policy conclusions that can be drawn as inputs into the policymaking process for supplementing the mutual interest of the countries.

The paper is arranged as follows: Section 2 provides the literature review. Section 3 reviews the bilateral trade relations between India and China. Section 4 presents the research methodology and data sources. Section 5 reports and discusses the GTAP CGE results, while section 6 provides concluding remarks. 


\section{Literature Review}

The debate to resolve regionalism versus multilateralism remains unsettled between 'building block' versus 'stumbling block' argument of regionalism in international trade. Viner (1950) drew a distinction between trade creating and trade diverting effects of free trade agreements or regionalism. He established that preferential trade need not necessarily improve the welfare of the members, and sometimes it reduces it by diverting trade from low-cost country to high-cost country. He explained the economic outcome of the regional integration in terms of 'trade creation' and 'trade diversion' effects. Since then, several studies have examined free trade agreements in the light of trade creating and trade diverting effects using either partial equilibrium or computable general equilibrium models using econometric or mathematical approaches.

Later, the benefits of regional integration were explained and technically refined over Viner (1950) by Meade (1955), Vanek (1965), Ohyama (1972) and Kemp and Wan (1976). Schott (1991) argues that the most desirable trading bloc comprises countries with the most diverse range of comparative advantage, which affords the greatest scope for trade creation and the least scope for trade diversion. Baldwin $(1993,2006)$ developed the Domino and Juggernaut theory of regionalism to support regional integration. Baldwin (2008) observed regionalism is here to stay, and there is a need for deep multilateral integration; instead, it is assisting its development.

Bhagwati (1990) argued that trading blocs are discriminatory and hence may be considered as an open threat to multilateralism. Bhagwati (1992) and Krueger (1997) articulated deep apprehensions regarding the negative impact of increasing regionalism. They were concerned that RTAs divert focus from the multilateral trading regime. Panagariya (2000) asserted that preferential trade agreements (PTAs) could divert trade and reduce welfare for the member countries.

The major factors limiting the regional economies include the commodity-based structure, restrictive trade policies, high tariffs, heavy transport costs, underdeveloped infrastructure, and cross border barriers (Tai \& Lee, 2019). While trade restrictions are invariably rationalised in terms of national welfare, in reality, they are usually advocated by those vested groups in the nation that stand to benefit from such trade barriers. Among these barriers, tariffs are the most common kind of barrier to trade. The empirical results confirm the existence of a long-term relationship between tariff reductions and trade growth at the world level. Theoretically, both the traditional and modern approaches to the theory of trade policy are in substantial agreement that tariffs produce distorting effects on the economy, leading to a suboptimal allocation of resources. In contrast, tariff liberalisation, in introducing changes to relative prices, leads to a better allocation of resources and, thus, increased production and consumption. From an empirical standpoint, some studies confirm the existence of a direct effect of tariff reduction on trade growth (Nenci, 2011). It has been observed in case of joining E.U. as a new 
member, the elimination of tariffs and other trade barriers led to a growth in trading activity. The expansion of trade was inevitable due to the free flow of goods at the common internal market, which was developed after the integration. However, any FTA/RTA/CU creates a number of possibilities as well as challenges (Vásáry, Vasa \& Baranyai, 2014).

Studies are also indicating that there is a technological shift in the specialisation of India and China over time. In the case of China, specialisation has increased in high technology and resource-based exports whereas decreased in case of lowtechnology and medium technology-based exports. It has been revealed that there is a sharp decline in the share of low-technology manufactures followed by resourcebased manufactures in China, whereas in India, exports are dominated by resourcebased manufactures, and low-technology manufactures. China's exports have been changing with an increasing share of skill-intensive, medium to high-technology products and decreasing share of labour-intensive products which means competition from China in labour-intensive products may decrease in the long run (Qureshi \& Wan, 2008; Bagaria \& Ismail, 2017, Bagaria \& Ismail, 2018).

In both China and India, agriculture is the key sector, and yet detailed comparisons of agricultural development in the two economies are difficult to obtain (Bardhan, 1970). Bhattacharya and Bhattacharya (2007) examines empirically the likely impact of preferential and free trade agreements between India and China using the Gravity Model under different comparative-static scenarios. They argued that Free trade arrangement is a win-win situation for both countries and is consistent with their growing dominance in international trade. Sharma (2008) argues that a formal trade agreement between India and China will mark a positive impact on agriculture also, and not just on the quantum of trade but also in its richness in terms of diversification to higher value-added products. Sharma and Kaur (2013) examine the causal relationships between FDI and trade (i.e. Exports and Imports) in India and China. They were indicating that more FDI into China leads to more imports, which in turn leads to more exports because of synergies created by this procedure. In this sense, inward FDI at an economy level in China can be regarded as efficiency-seeking, which increases the volume of trade. However, there exist bidirectional causality between FDI and imports; FDI and exports and Imports and exports in case of India.

Theoretical literature that discusses the expected impact of PTAs/FTAs depends on whether or not trade creation exceeds trade diversion, and what happens to the terms-of-trade. Although newer trade theory attempts to enhance the understanding of the impact of PTAs on the global economy by incorporating issues such as rising investment opportunities, enhanced productivity, sharpened competition, increased utilisation of scale economies, etc. However, the measurement of such effects is difficult and ambiguous at best. Moreover, trade liberalisation takes place in a second-best world characterised by imperfect competition and domestic policy distortions. The bottom line of the theoretical debate, however, is that there are very few clear-cut conclusions. The outcome 
depends on the precise context. Hence, it is ultimately an empirical question whether the creation of a PTA enhances welfare, whether the trade is diverted from nonmembers, and whether PTAs support the ultimate goal of global free trade.

Multilateralism has been put on hold and nations have often opted for regionalism in trade and investment since the last one and half-decade. Each country is engaged in bilateral FTAs or RTAs in the global trade policy framework. As of 20 September 2020, 306 RTAs were in force. These correspond to 496 notifications from WTO members, counting goods, services, and accessions separately. Given a lack of global pursuit for meaningful movement in the multilateral process of trade liberalisation, India and China need to explore alternative ways of bilateral engagements as a second-best option towards agriculture trade liberalisation. In view of the above, the present study strives to find out future trade possibilities or potentials between India and China in agriculture trade. Before proceeding further, it is essential to know the current status of agriculture trade relations and applied tariff rates between these two countries.

\section{Pattern of India-China Agriculture Trade}

India's trade sector contributes substantially to the Indian Economy. Its global exports and imports have gone up from USD 42.36 and USD 52.94 billion in 2000 to USD 322.29 and USD 617.95 billion in 2018 respectively. At present, there is a huge trade deficit of USD 295.66 billion in trade in goods. The bilateral trade between India and China has grown manifolds since 2000. Trade statistics indicate that India's exports to China have gone up from USD 0.73 billion in 2000 to USD 16.37 billion in 2018 while India's imports from China has gone up from USD 1.48 billion in 2000 to USD 90.40 billion in 2018. Bilateral trade between China and India touched USD 106.77 billion in 2018, with India's trade deficit widening to USD 74.03 billion (U.N. Comtrade Database).

Table 1 presents the gross agricultural exports of India and China. In 2003, India's agricultural exports to China was merely USD 0.09 billion out of India's global agricultural exports of USD 5.86 billion. It was $1.54 \%$ of India's global exports. In 2013, India's agricultural exports to China reached USD 3.87 billion, while India's global agricultural exports were USD 42.32 billion. It was $9.14 \%$ of India's global exports. Since 2013 onwards, there is a decline in India's global agricultural exports and so to China. In 2018, India's agricultural exports to China was USD 1.08 billion out of India's global agricultural exports of USD 31.94 billion. It was $3.38 \%$ of India's global exports. In the case of China, agricultural exports to India was USD 0.23 billion while China's global agricultural exports were USD 13.51 billion in 2003. In 2018, China's agricultural exports to India was USD 0.64 billion out of China's global agricultural exports of USD 54.62 billion. During 2003-18, China's agricultural exports to India lies between $1 \%$ to $2 \%$ of its global agricultural exports (Figure $1 \& 2$ ). In agricultural trade, the balance of trade is in favour of India, but it is a marginal amount. 
Is 'WTO-Plus' a Policy Option for India-China Agriculture Trade? A CGE Analysis

Table 1. Gross Agricultural Exports (in Billion USD)

\begin{tabular}{|c|c|c|c|c|c|c|c|}
\hline \multirow[b]{2}{*}{ Year } & \multicolumn{3}{|c|}{ India's Gross Exports } & \multirow[b]{2}{*}{ Year } & \multicolumn{3}{|c|}{ China's Gross Exports } \\
\hline & China & World & \%age & & India & World & \%age \\
\hline 2003 & 0.09 & 5.86 & 1.54 & 2003 & 0.23 & 13.51 & 1.70 \\
\hline 2010 & 2.42 & 20.44 & 11.84 & 2010 & 0.48 & 28.92 & 1.66 \\
\hline 2011 & 3.39 & 30.83 & 11.00 & 2011 & 0.52 & 35.64 & 1.46 \\
\hline 2012 & 3.68 & 39.18 & 9.39 & 2012 & 0.55 & 43.10 & 1.28 \\
\hline 2013 & 3.87 & 42.32 & 9.14 & 2013 & 0.58 & 44.41 & 1.31 \\
\hline 2014 & 2.04 & 37.36 & 5.46 & 2014 & 0.60 & 47.58 & 1.26 \\
\hline 2015 & 0.93 & 29.60 & 3.14 & 2015 & 0.63 & 50.38 & 1.25 \\
\hline 2016 & 0.82 & 27.32 & 3.00 & 2016 & 0.55 & 50.46 & 1.09 \\
\hline 2017 & 0.93 & 31.43 & 2.96 & 2017 & 0.61 & 52.54 & 1.16 \\
\hline 2018 & 1.08 & 31.94 & 3.38 & 2018 & 0.64 & 54.62 & 1.17 \\
\hline
\end{tabular}

Source: U.N. Comtrade Database, Retrieved from WITS (Accessed on 20 January 2020)

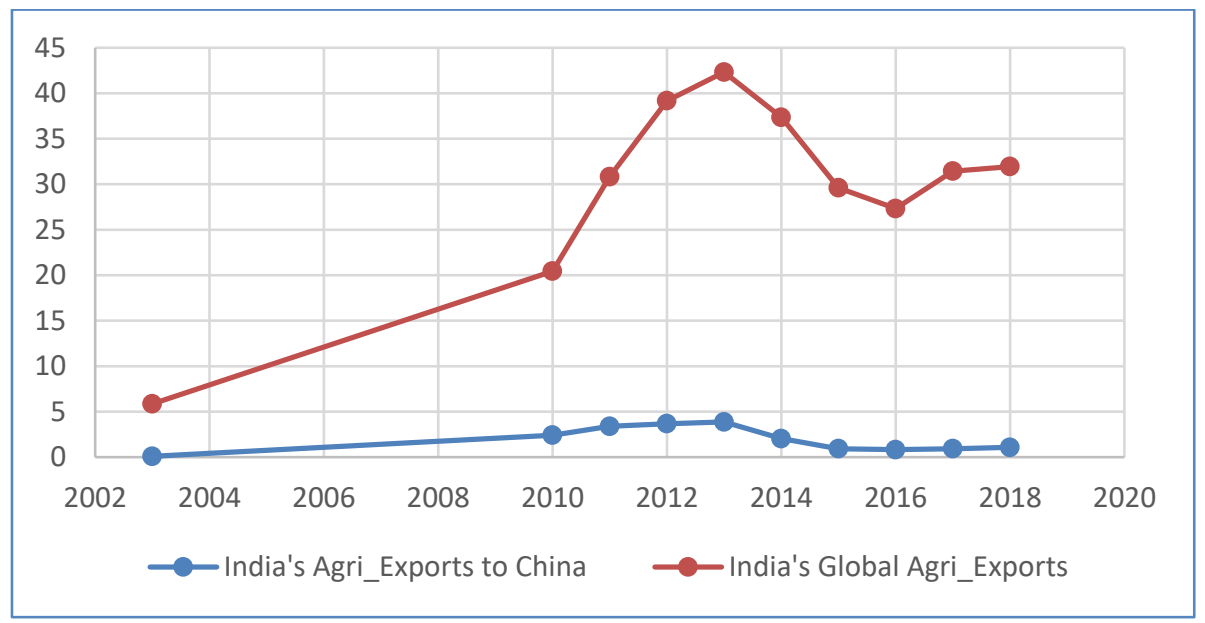

Figure 1. India's Trend of Agricultural Exports

Source: Authors' Plot using U.N. Comtrade Database

From the perspective of future trade, it is important to examine the trend and structure of bilateral agricultural tariff rate between India and China. Globally, the barriers to South-South trade are higher than those with developed countries. The same is applicable to India-China trade relations. Table 2 gives MFN applied tariff rates on imports of India and China. The tariff statistics indicate that the simple average tariff rate of India was $43.02 \%$ in 2000 , which was reduced to $30.42 \%$ in 2018. Weighted average tariff rate in India was $34.7 \%$ in 2000 , which was reduced to $25.64 \%$ in 2018. 


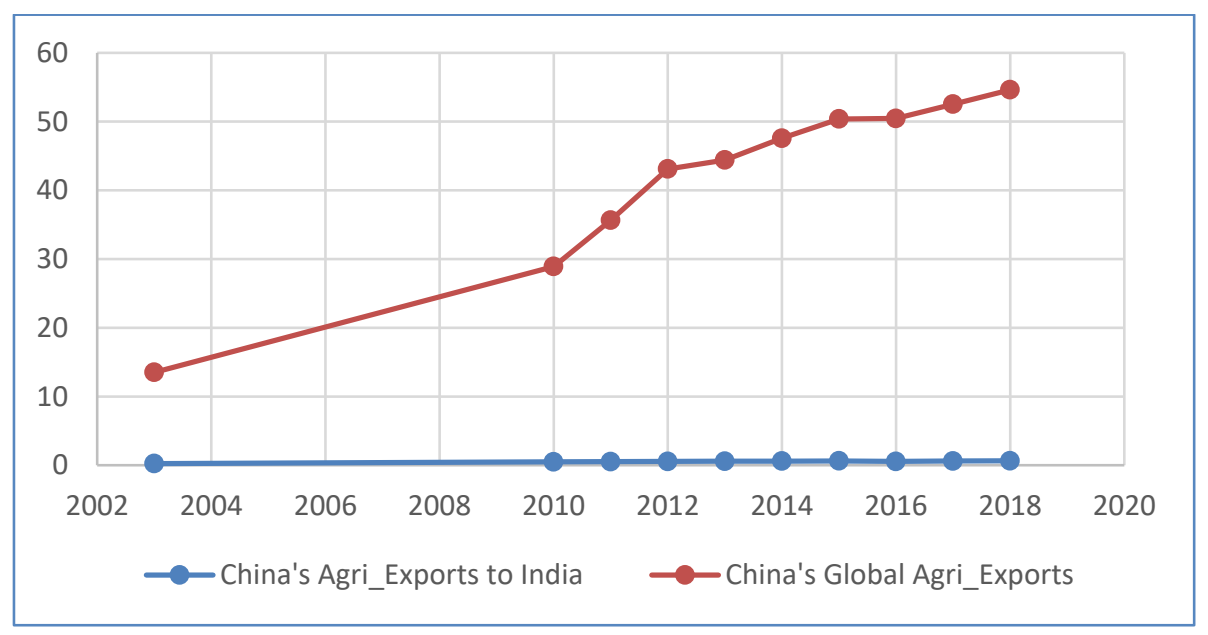

Figure 2. China's Trend of Agricultural Exports

Source: Authors' Plot using U.N. Comtrade Database

Similarly, the simple average tariff rate in China was $20.48 \%$ in 2000 , which was reduced to 13.97 in 2018 . Weighted average tariff rate of China was $12.53 \%$ in 2000, which was increased to $16.33 \%$ in 2018. It can be inferred that both India and China have reduced their agricultural tariffs marginally on a unilateral basis or under multilateral commitments. Agricultural tariff rate of India is relatively higher compared to China. From the protection statistics, it seems agriculture is a protected sector in both economies. However, the level of protection differs significantly in terms of their commodities coverage and depth of tariff protection.

Table 2. MFN Applied Agricultural Tariff Rate of India and China

\begin{tabular}{lllll}
\hline & India & \multicolumn{3}{l}{ China } \\
\cline { 2 - 5 } Tariff Year & Simple Average & $\begin{array}{l}\text { Weighted } \\
\text { Average }\end{array}$ & Simple Average & $\begin{array}{l}\text { Weighted } \\
\text { Average }\end{array}$ \\
\hline 2000 & 43.02 & 34.7 & 20.48 & 12.53 \\
\hline 2005 & 37.65 & 30.77 & 13.97 & 16.33 \\
\hline 2010 & 34.9 & 31.97 & 15.3 & 8.13 \\
\hline 2015 & 30.66 & 20.88 & 14.95 & 11.29 \\
\hline 2016 & 31.78 & 27.65 & 15.02 & 11.08 \\
\hline 2017 & 31.58 & 27.95 & 15.02 & 11.08 \\
\hline 2018 & 30.42 & 25.64 & 13.97 & 16.33 \\
\hline
\end{tabular}

Source: Trains Database, Retrieved from WITS (Accessed on 10 May 2020)

\section{Methodology and Data Sources}

The methodological framework of this paper for examining the economy-wide impact of tariff liberalisation between India and China is based on the GTAP model. 
The GTAP model is based on neoclassical theories and uses the only publicly available common global dataset for the economy-wide analysis, the GTAP database 10 (Aguiar et al., 2019). The model is a comparative-static standard multi-regional computable general equilibrium (CGE) model. A CGE model numerically simulates the general equilibrium structure of the economy. The model provides an elaborate representation of the economy, including the linkages between various sectors.

The standard version of the GTAP model includes several key assumptions. First, perfect competition and a constant return to scale are assumed. Second, imperfect substitution in goods and services between the home economy and those abroad and among different origins of economies are assumed by the Armington parameters. Third, the model assumes full employment. The amount of total capital is also fixed in the standard GTAP model. In the model, the price received by the producer is the same as the producer's marginal cost. By imposing taxes and subsidies on commodities and primary factors, the regional government can drive wedges between prices paid by purchasers and prices received by producers. These policy interventions are modelled as ad valorem taxes, tariffs, and subsidies. Its theory is documented in Hertel (1997) and implemented using the GEMPACK software (Harrison \& Pearson, 1996).

Each region in the model has a single representative household. The representative household's aggregate income is exhausted through constant share to private household consumption, government expenditures and national savings. The private household buys bundled of commodities to maximise utility subject to its expenditure constraint. The constrained optimising behaviour of the private household is represented by Constant Difference Elasticity (CDE) demand system. The bundles are CES combinations of domestic goods and import bundles, with the import bundles being CES aggregations of imports from each region. Government expenditure is allocated across commodities by a Cobb-Douglas distribution. The allocation of total expenditure on each good to domestically produced and imported versions is based on the same nesting scheme used to allocate total household expenditure on each good. Investment in each region is financed from a global pool of savings.

There are two types of inputs used for production, i.e., intermediate inputs and primary factors. In the model, there are five types of factors of production in each region, namely skilled labour, unskilled labour, capital good, land and other natural resources. In the typical closure of the model, total supplies of labour and land are fixed for each region, but capital can cross regional borders to equalise changes in rates of return. A three-level nested production technology constrains the sectors' inputs choice. Due to the forward and backward linkages and their related strength existing in a particular economy, the result is always the changes in the relative mix of the different factors of production in the different sectors. The country-level effects on output mix and demand for factors of production can be extended to the interrelated partner economies. The general equilibrium methodology provides an 
analytical framework that allows for these inter and intra-sectoral changes in the output mix, and the demand for different factors of production is captured.

This model is widely used to capture effects of changing trade policies at the country, bilateral, regional, and multilateral levels on the output mix, factor usage, trade effects and resultant welfare distribution between countries. Since the model lay emphasis on resource reallocation across economic sectors, it is a good instrument for identifying the winning and losing countries and sectors under policy changes involving the trade aspects of the RTAs/FTAs/EPAs (Ahmed, 2010; Ahmed, 2011).

\subsection{The GTAP Database and the Aggregation Scheme}

The GTAP model uses the GTAP database, a global data set for CGE modelling. In the present study, GTAP database version 10A, covering 141 countries/regions and 65 sectors, with the base year of 2014, has been used. All the trade flows for the 65 commodity categories are distinguished by their countries/regions of origin and destination, and on the basis of agents such as intermediate demand, final demand by private households, government and investment. It provides a method for allowing for varying import intensities by different economic agents within a country/region. The tariff data is mainly in the form of applied ad valorem rates. In the present analysis, 141 countries/regions are aggregated into five countries/regions, and 65 commodities are aggregated into three commodity groups. Details of regional and sectoral aggregation are presented in Appendix-1A and $2 A$.

\subsection{Simulation Scenarios}

To examine the potential effects of tariff removal by India and China on imports of agricultural goods from each other, four hypothetical scenarios are simulated:

- Scenario-I considers 50 per cent tariff cut by India and China on agricultural imports from each other. Default GTAP closures are adopted.

- Scenario-II considers 50 per cent tariff cut by India and China on agricultural imports from each other. This simulation is undertaken on the basis of modified GTAP closures for India and China.

- Scenario-III considers 100 per cent tariff cut by India and China on agricultural imports from each other. Default GTAP closures are adopted.

- Scenario-IV considers 100 per cent tariff cut by India and China on agricultural imports from each other. This simulation is undertaken on the basis of modified GTAP closures for India and China, similar to Scenario-II.

The simulations in scenario-II and IV have captured unskilled employment effects while doing simulations. In both countries, there is an excess supply of unskilled labour, which can be drawn on by industries in the event of increased production. An assumption of full employment is inappropriate for countries like India and China. To capture the realities of Indian and Chinese labour market, the real wage rate was fixed exogenously, and the supply of labour is endogenised (Ahmed, 2011). The 
present model is solved using the Gragg method in 2-4-6 steps extrapolation. In this case, the model is solved several times, each time with a successively finer grid. An extrapolated solution is formed based on these results (Hertel \& Tsigas,1997). The outcomes of the simulations are reported in terms of its effect on welfare, output, employment, imports, and exports.

\section{GTAP Model Simulation Results}

The effects of bilateral agricultural tariff liberalisation on the welfare changes of households in a region are the most important variable. The result of welfare effects is reported in table 3 . In GTAP, welfare effects are measured using the equivalent variations (E.V.). In the scenario I, GTAP results reveal that welfare effect is positive for both India and China. Welfare gain for India and China is USD 12 million and USD 52.9 million, respectively. Net global welfare increases by USD 32.3 million. However, there is a welfare loss of USD -20.4 million for ASEAN, USD -1.72 million for the rest of South Asia and USD-10.4 million for the rest of the world. In this scenario, allocative efficiency will be improving for India by USD 34.5 million and deteriorating for China by USD -6.99 million. India's terms of trade deteriorate by USD -20.6 million while improving for China by USD 65.2 million.

In scenario II, welfare effect is positive for both India and China. Welfare gain for India and China is USD 51.9 million and USD 50.7 million, respectively. The net global welfare increase is USD 71.1 million. However, there is a welfare loss of USD -20.3 million for ASEAN, USD -1.74 million for the rest of South Asia and USD -9.56 million for the rest of the world. In this scenario, allocative efficiency will be improving for India by USD 38.8 million and deteriorating for China by USD-7.45 million as a result of tariff reduction. Though, India's terms of trade deteriorate by USD -21.6 million while improving for China by USD 65.4 million. Employment for unskilled labour will be increasing by USD 37.2 million for India and decreasing by USD -1.93 million for China.

In scenario III, simulation results reveal that welfare loss for India is USD-121 million and welfare gains for China are USD 142 million. The net global welfare decreases by USD -39.4 million. There is a welfare loss of USD -52.3 million for ASEAN, USD -3.2 million for the rest of South Asia and USD -4.55 million for the rest of the world. In this scenario, allocative efficiency will be deteriorating both for India and China by USD -14.2 million and USD -40.7 million, respectively. India's terms of trade deteriorate by USD -95.3 million while improving for China by USD 197 million. Net global effects on allocative efficiency are negative and will be decreasing by USD 39.3 million.

In scenario IV, welfare effect is similar to scenario III in direction. Welfare loss for India is USD -6.53 million, while welfare gain for China is USD 118 million. Net global welfare increases by USD 54.5 million. However, there is a welfare loss of USD -52 million for ASEAN, USD -3.25 million for the rest of South Asia and USD -2.15 million 
Shahid AHMED \& Saba ISMAIL

for the rest of the world. In this scenario, allocative efficiency will be improving for India by USD 3.31 million and deteriorating for China by USD-45.6 million. India's terms of trade deteriorate by USD -98.1 million and improve for China by USD 197 million. Net global effects on allocative efficiency are negative and will be decreasing by USD - 27.3 million. The endowment effect is positive and will be increasing by USD 101 million for India and decreasing by USD -19.6 million for China.

Table 3. Welfare and its Components (in Millions USD)

\begin{tabular}{|c|c|c|c|c|c|}
\hline $\begin{array}{l}\text { Country } \\
\text { Groups }\end{array}$ & $\begin{array}{l}\text { Allocative } \\
\text { Efficiency effects }\end{array}$ & $\begin{array}{l}\text { Endowment } \\
\text { Effect }\end{array}$ & $\begin{array}{l}\text { Change in } \\
\text { Terms of Trade }\end{array}$ & $\begin{array}{l}\text { Change in } \\
\text { Capital Stock }\end{array}$ & Total \\
\hline \multicolumn{6}{|c|}{ Scenario-I } \\
\hline India & 34.5 & 0 & -20.6 & -1.99 & 12 \\
\hline China & -6.99 & 0 & 65.2 & -5.4 & 52.9 \\
\hline ASEAN & 0.454 & 0 & -21.7 & 0.877 & -20.4 \\
\hline RSA & -0.197 & 0 & -0.67 & -0.84 & -1.72 \\
\hline ROW & 4.47 & 0 & -22.3 & 7.37 & -10.4 \\
\hline Total & 32.3 & 0 & -0.002 & 0 & 32.3 \\
\hline \multicolumn{6}{|c|}{ Scenario-II } \\
\hline India & 38.8 & 37.2 & -21.6 & -2.44 & 51.9 \\
\hline China & -7.45 & -1.93 & 65.4 & -5.25 & 50.7 \\
\hline ASEAN & 0.443 & 0 & -21.6 & 0.899 & -20.3 \\
\hline RSA & -0.203 & 0 & -0.692 & -0.844 & -1.74 \\
\hline ROW & 4.27 & 0 & -21.5 & 7.64 & -9.56 \\
\hline Total & 35.8 & 35.3 & -0.002 & 0 & 71.1 \\
\hline \multicolumn{6}{|c|}{ Scenario-III } \\
\hline India & -14.2 & 0 & -95.3 & -12 & -121 \\
\hline China & -40.7 & 0 & 197 & -14.2 & 142 \\
\hline ASEAN & 1.92 & 0 & -57.1 & 2.85 & -52.3 \\
\hline RSA & -0.433 & 0 & -0.359 & -2.4 & -3.2 \\
\hline ROW & 14 & 0 & -44.3 & 25.7 & -4.55 \\
\hline Total & -39.3 & 0 & -0.025 & -0.002 & -39.4 \\
\hline \multicolumn{6}{|c|}{ Scenario-IV } \\
\hline India & 3.31 & 101 & -98.1 & -13.2 & -6.53 \\
\hline China & -45.6 & -19.6 & 197 & -13.8 & 118 \\
\hline ASEAN & 1.89 & 0 & -56.8 & 2.92 & -52 \\
\hline RSA & -0.448 & 0 & -0.407 & -2.39 & -3.25 \\
\hline ROW & 13.6 & 0 & -42.2 & 26.5 & -2.15 \\
\hline Total & -27.3 & 81.8 & -0.026 & -0.002 & 54.5 \\
\hline
\end{tabular}

Source: Authors' estimates based on GTAP Model Simulations 
The effects of bilateral agricultural tariff liberalisation on sectoral output are reported in Table 4. In scenario-I, the output of all commodity groups changes by $0.002 \%$ and $-0.002 \%$ in India and China, respectively. Agricultural output is expected to fall in India while it is expected to rise in the case of China. In scenario-II, the output of all commodity groups changes by $0.004 \%$ and $-0.002 \%$ in India and China, respectively. Agricultural output changes by $-0.020 \%$ and $0.020 \%$ in India and China, respectively. In scenario-III, GTAP results indicate a change in a similar direction, though the magnitude of change varies. Agricultural output changes by $-0.070 \%$ and $0.070 \%$ in India and China, respectively. In scenario-IV, the output of all commodity groups changes by $0.013 \%$ and $-0.005 \%$ in India and China, respectively. Agricultural output changes by $-0.060 \%$ and $0.070 \%$ in India and China, respectively. The simulation results reveal a marginal decline in agricultural output for India while a marginal increase in agricultural output for China.

\section{Table 4. Change in Output Effect (\%)}

\begin{tabular}{llllll}
\hline Commodity Groups & India & China & ASEAN & RSA & ROW \\
\hline Scenario-I & & & & & \\
\hline Agr & -0.020 & 0.020 & -0.010 & 0.000 & 0.000 \\
\hline Mnfc & 0.010 & -0.010 & 0.010 & 0.010 & 0.000 \\
\hline Services & 0.000 & 0.000 & 0.000 & 0.000 & 0.000 \\
\hline Total & 0.002 & -0.002 & 0.001 & 0.001 & 0.000 \\
\hline Scenario-II & & & & & \\
\hline Agr & -0.020 & 0.020 & -0.010 & 0.000 & 0.000 \\
\hline Mnfc & 0.010 & -0.010 & 0.010 & 0.010 & 0.000 \\
\hline Services & 0.000 & 0.000 & 0.000 & 0.000 & 0.000 \\
\hline Total & 0.004 & -0.002 & 0.001 & 0.001 & 0.000 \\
\hline Scenario-III & & & & & \\
\hline Agr & -0.070 & 0.070 & -0.040 & -0.010 & -0.010 \\
\hline Mnfc & 0.050 & -0.020 & 0.020 & 0.020 & 0.000 \\
\hline Services & 0.000 & 0.000 & 0.000 & 0.000 & 0.000 \\
\hline Total & 0.008 & -0.005 & 0.002 & 0.002 & 0.000 \\
\hline Scenario-IV & & & & & \\
\hline Agr & -0.060 & 0.070 & -0.040 & -0.010 & -0.010 \\
\hline Mnfc & 0.050 & -0.020 & 0.020 & 0.020 & 0.000 \\
\hline Services & 0.010 & 0.000 & 0.000 & 0.000 & 0.000 \\
\hline Total & 0.013 & -0.005 & 0.002 & 0.002 & 0.000 \\
\hline
\end{tabular}

Source: Authors' estimates based on GTAP Model Simulations

The changes in sectoral employment are reported in table 5. The result of scenario-I is based on the standard closures of the GTAP model, which implies full employment of labour in India and China. The simulation results only reflect a reallocation of labour in different sectors as a result of mutual bilateral tariff liberalisation. In the case of India, the simulation result of scenario I for the employment of unskilled labour indicates a decline for the agriculture sector by $-0.03 \%$ while an increase in the agriculture sector by $0.03 \%$ in China. In the manufacturing sector, employment of unskilled labour increases by $0.01 \%$ in India while a decrease of $-0.01 \%$ in China. 
It can be inferred from simulation results that there will be a reallocation of labour from agriculture to the manufacturing sector in India while reverse reallocation of labour may take place in China.

The result of scenario-II is based on the modified standard closures for both India and China. An excess supply of unskilled labour is incorporated in the model, which implies that excess labour can be drawn on by industries in the event of increased production at given wages. In the case of India, the demand for unskilled labour increases by $0.02 \%$, with a decrease in the agriculture sector by $-0.02 \%$ and an increase in the manufacturing sector by $0.03 \%$. In the case of China, the demand for unskilled labour remains unchanged, with an increase in the agriculture sector by $0.03 \%$ and a decrease in the manufacturing sector by $-0.01 \%$.

The simulation results of scenario III for the employment of unskilled labour indicates a decline in the agriculture sector by $-0.01 \%$ in India while an increase in the agriculture sector by $0.09 \%$ in China. In the case of the manufacturing sector, the simulation result of scenario III indicates an increase in employment of unskilled labour by $0.04 \%$ in India while a decrease of $-0.02 \%$ in China. It can be inferred from simulation results that there will be a reallocation of labour from agriculture to the manufacturing sector in India while reverse reallocation of labour may take place in China.

Table 5. Change in Demand for Unskilled Labour (\%)

\begin{tabular}{llllll}
\hline Commodity Groups & India & China & ASEAN & RSA & ROW \\
\hline Scenario-I & & & & & \\
\hline Agr & -0.03 & 0.03 & -0.02 & -0.01 & 0 \\
\hline Mnfc & 0.01 & -0.01 & 0.01 & 0.01 & 0 \\
\hline Services & 0 & 0 & 0 & 0 & 0 \\
\hline Total & 0.00 & 0.00 & 0.00 & 0.00 & 0.00 \\
\hline Scenario-II & & & & & \\
\hline Agr & -0.02 & 0.03 & -0.02 & -0.01 & 0 \\
\hline Mnfc & 0.03 & -0.01 & 0.01 & 0.01 & 0 \\
\hline Services & 0.02 & 0 & 0 & 0 & 0 \\
\hline Total & 0.02 & 0.00 & 0.00 & 0.00 & 0.00 \\
\hline Scenario-III & & & & & \\
\hline Agr & -0.1 & 0.09 & -0.05 & -0.02 & -0.01 \\
\hline Mnfc & 0.04 & -0.02 & 0.02 & 0.02 & 0 \\
\hline Services & 0 & 0 & 0 & 0 & 0 \\
\hline Total & 0.00 & 0.00 & 0.00 & 0.00 & 0.00 \\
\hline Scenario-IV & & & & & \\
\hline Agr & -0.07 & 0.09 & -0.05 & -0.02 & -0.01 \\
\hline Mnfc & 0.09 & -0.02 & 0.02 & 0.02 & 0 \\
\hline Services & 0.05 & 0 & 0 & 0 & 0 \\
\hline Total & 0.05 & 0.00 & 0.00 & 0.00 & 0.00 \\
\hline Source Auths & & 0 & &
\end{tabular}

Source: Authors' estimates based on GTAP Model Simulations 
The result of scenario-IV is based on the modified standard closures for both India and China and similar to scenario-II. In the case of India, the demand for unskilled labour increases by $0.05 \%$, with a decrease in the agriculture sector by $-0.07 \%$ and an increase in the manufacturing sector by $0.09 \%$. In the case of China, the demand for unskilled labour remains unchanged, with an increase in the agriculture sector by $0.09 \%$ and a decrease in the manufacturing sector by $-0.02 \%$. India seems to gain more in manufacturing sectors while China seems to benefit in the agriculture sector.

In all scenarios, such changes might bring a negative change in demand for unskilled labour in the agriculture sector in ASEAN countries.

Table 6 provides a change in global imports due to mutual prospective tariff reduction by India and China on imports of agricultural goods from each other. In simulation scenario-I, the results indicate an increase in global imports of India and China by $0.06 \%$ and $0.01 \%$ respectively. The results indicate an increase in India's global imports of agricultural commodities by $0.98 \%$. In China, the results indicate an increase in China's global imports of agricultural commodities by $0.09 \%$. The results of Scenario-Il indicate a change in global imports in a similar direction to Scenario-I. In simulation scenario III, the results indicate an increase in global imports of India and China by $0.14 \%$ and $0.01 \%$ respectively.

Table 6. Changes in Global Imports (\%)

\begin{tabular}{|c|c|c|c|c|c|}
\hline Commodity Groups & India & China & ASEAN & RSA & ROW \\
\hline \multicolumn{6}{|l|}{ Scenario-I } \\
\hline Agr & 0.98 & 0.09 & -0.01 & 0 & 0 \\
\hline Mnfc & 0 & 0 & 0 & 0 & 0 \\
\hline Services & 0 & 0 & 0 & 0 & 0 \\
\hline Total & 0.06 & 0.01 & 0.00 & 0.00 & 0.00 \\
\hline \multicolumn{6}{|l|}{ Scenario-II } \\
\hline Agr & 0.99 & 0.09 & -0.01 & 0 & 0 \\
\hline Mnfc & 0 & 0 & 0 & 0 & 0 \\
\hline Services & 0 & 0 & 0 & 0 & 0 \\
\hline Total & 0.06 & 0.01 & 0.00 & 0.00 & 0.00 \\
\hline \multicolumn{6}{|l|}{ Scenario-III } \\
\hline Agr & 2.64 & 0.22 & -0.04 & 0.02 & 0 \\
\hline Mnfc & -0.01 & 0.01 & 0 & 0 & 0 \\
\hline Services & -0.03 & 0.01 & 0 & -0.01 & 0 \\
\hline Total & 0.14 & 0.02 & 0.00 & 0.00 & 0.00 \\
\hline \multicolumn{6}{|l|}{ Scenario-IV } \\
\hline Agr & 2.65 & 0.22 & -0.04 & 0.01 & 0 \\
\hline Mnfc & 0 & 0.01 & 0 & 0 & 0 \\
\hline Services & -0.03 & 0.01 & 0 & -0.01 & 0 \\
\hline Total & 0.15 & 0.02 & 0.00 & 0.00 & 0.00 \\
\hline
\end{tabular}

Source: Authors' estimates based on GTAP Model Simulations

The results indicate an increase in India's global imports of agricultural commodities by $2.64 \%$ while China's global imports of agricultural commodities increase by $0.22 \%$. 
The results indicate a two and half times increase in scenario-III compared to scenario-II. In simulation scenario IV, the results indicate an increase in global imports of India and China by $0.15 \%$ and $0.02 \%$ respectively. The results indicate an increase in India's global imports of agricultural commodities by $2.65 \%$ while China's global imports of agricultural commodities by $0.22 \%$.

Table 7 provides a change in global exports due to mutual prospective tariff reduction by India and China on imports of agricultural commodities from each other. In simulation scenario-I, the results indicate an increase in global exports of India and China by $0.07 \%$ and $0.01 \%$ respectively. The results indicate an increase in India's global exports by $0.51 \%$ in agriculture, respectively. In the case of China, global exports of agricultural commodities increased by $0.81 \%$. The change in global exports is similar in magnitude as well as the direction in Scenario-II. Scenario-III results indicate an increase in India's global exports by $0.21 \%$, with an increase in agriculture by $1.21 \%$ while China's global exports rise by $0.02 \%$, with an increase in agriculture by $2.34 \%$. Scenario-IV results are similar to the results of Scenario-III.

Table 7. Change in Global Exports (\%)

\begin{tabular}{llllll}
\hline Commodity Groups & India & China & ASEAN & RSA & ROW \\
\hline Scenario-I & & & & & \\
\hline Agr & 0.51 & 0.81 & -0.07 & -0.1 & -0.02 \\
\hline Mnfc & 0.02 & -0.02 & 0.01 & 0.02 & 0 \\
\hline Services & 0.01 & -0.01 & 0.01 & 0.01 & 0 \\
\hline Total & 0.07 & 0.01 & 0.00 & 0.00 & 0.00 \\
\hline Scenario-II & & & & & \\
\hline Agr & 0.51 & 0.81 & -0.07 & -0.1 & -0.02 \\
\hline Mnfc & 0.02 & -0.02 & 0.01 & 0.02 & 0 \\
\hline Services & 0.01 & -0.01 & 0.01 & 0.01 & 0 \\
\hline Total & 0.07 & 0.01 & 0.00 & 0.00 & 0.00 \\
\hline Scenario-III & & & & & \\
\hline Agr & 1.21 & 2.34 & -0.18 & -0.27 & -0.05 \\
\hline Mnfc & 0.12 & -0.05 & 0.02 & 0.04 & 0.01 \\
\hline Services & 0.07 & -0.02 & 0.01 & 0.02 & 0 \\
\hline Total & 0.21 & 0.02 & 0.00 & 0.00 & 0.00 \\
\hline Scenario-IV & & & & & \\
\hline Agr & 1.20 & 2.34 & -0.18 & -0.27 & -0.05 \\
\hline Mnfc & 0.12 & -0.05 & 0.02 & 0.04 & 0.01 \\
\hline Services & 0.07 & -0.02 & 0.01 & 0.02 & 0 \\
\hline Total & 0.21 & 0.02 & 0.00 & 0.00 & 0.00 \\
\hline Source Auths & & & &
\end{tabular}

Source: Authors' estimates based on GTAP Model Simulations

Table 8 provides a change in bilateral exports of agricultural commodities. To examine the effects of tariff cut, the change in bilateral exports are important rather than global export flows. The simulation result in scenario-l indicates an increase of $0.75 \%$ in India's exports to China, with an increase in agricultural exports of $8.06 \%$ while China's exports to India increased by $0.78 \%$, with an increase of $67.80 \%$ in 
agricultural exports. Results of Scenario-II indicates a similar change in bilateral exports as reported in Scenario-I. Scenario-III conceptualises a zero-tariff regime from each other. The results indicate an increase of $1.64 \%$ in Indian exports to China, with an increase in agricultural exports of $17.11 \%$ while China's exports to India increased by $2.25 \%$, with an increase of $197.54 \%$ in agricultural exports. Scenario-IV simulation results indicate a similar change in bilateral exports as reported in Scenario-III.

Table 8. Change in Bilateral Exports (\%)

\begin{tabular}{lllll}
\hline \multirow{2}{*}{ Commodity Groups } & India to China & China to India & India to China & China to India \\
\cline { 2 - 5 } & Scenario-I & & Scenario-II \\
\hline Agr & 8.06 & 67.80 & 8.05 & 67.85 \\
\hline Mnfc & 0.02 & -0.01 & 0.02 & -0.01 \\
\hline Services & 0.02 & 0.00 & 0.02 & -0.01 \\
\hline Total & 0.75 & 0.78 & 0.75 & 0.78 \\
\hline Commodity Groups & Scenario-III & & Scenario-IV \\
\hline Agr & 17.11 & 197.54 & 17.1 & 197.57 \\
\hline Mnfc & 0.12 & -0.05 & 0.12 & -0.05 \\
\hline Services & 0.08 & -0.06 & 0.09 & -0.06 \\
\hline Total & 1.64 & 2.25 & 1.64 & 2.25 \\
\hline Sot & & & &
\end{tabular}

Source: Authors' estimates based on GTAP Model Simulations

\section{Concluding Remarks}

The present study suggests that partial tariff reduction (Scenario-I\&II) on imports of agricultural commodities between India and China may be welfare-enhancing for both countries. The net global welfare also increases, though, there is a welfare loss for ASEAN, rest of South Asia and the rest of the world. In this scenario, allocative efficiency will be improving for India and deteriorating for China. India's terms of trade deteriorate while improving for China. However, zero tariffs on imports of agricultural commodities (Scenario-III\&IV) may not be welfare-enhancing for India, yet there will be substantial welfare gain for China. India's terms of trade deteriorate while improves for China in zero-tariff structure also. It is revealed that India gains in terms of unskilled employment and improvement in allocative efficiency, whereas China gains mainly in terms of trade.

The simulation results reveal a marginal decline in agricultural output for India while a marginal increase in agricultural output for China. It can be inferred from simulation results that there will be a reallocation of labour from agriculture to the manufacturing sector in India while reverse reallocation of labour may take place in China. India seems to gain more in manufacturing sectors while China seems to benefit in the agriculture sector. It may increase poverty in India, particularly among farmers. The study suggests that the tariff liberalisation in the agriculture sector will have a positive impact on global imports, global exports and bilateral exports of agricultural commodities both in India and China. 
The study also establishes that welfare gains for China are larger in comparison to the welfare gains of India in all scenarios. In case of deeper tariff cuts on a parity basis, India will be a net loser in the process. The study corroborates the fear that there would be a surge in imports of agricultural commodities from China to the Indian market. Yet it is not implied that there is no further scope of economic cooperation between these two big emerging economies. The study indicates that a well calculated and strategically negotiated partial tariff reduction may create a winwin situation for both partners. This has been highlighted in Scenario-I and II. China may offer preferential market access to India for any meaningful engagements for both countries. But it is be noted that negotiating space in agriculture trade liberalisation is narrow. India needs to assess all pros and cons as it has revenue loss and impact on economically marginalised section, i.e. the 'Farming Community.'

It is to be further noted that the present study assessed only the potential effects of tariff reduction scenarios in the agriculture sector between India and China and not assessed the other provisions of such an FTA. There is a scope for further research in the context of other provisions of an FTA engagement. Also, a more disaggregated study will be further useful for product-wise policy decision making.

\section{Acknowledgements}

The authors gratefully acknowledge the constructive comments and suggestions of anonymous referees and editor of this Journal.

\section{References}

Aguiar, A., Chepeliev, M., Corong, E., McDougall, R., \& van der Mensbrugghe, D. (2019). The GTAP Data Base: Version 10. Journal of Global Economic Analysis, 4(1), 1-27. https://doi.org/10.21642/JGEA.040101AF

Ahmed, S. (2010). India's Trade with South vs North: Alternative Option. Asian Economic Review, 50 (3), 445-462.

Ahmed, S. (2011). Economic and Welfare Impacts of Prospective India - Australia FTA Using GTAP and Smart Models. International Journal of Business and Emerging Markets. 3(4), 396417. https://doi.org/10.1504/IJBEM.2011.042999

Bagaria, N. \& Ismail, S. (2017). An Analysis of Specialisation of Indian Exports. Indian Journal of Economics, 98 (388), 47-58.

Bagaria, N. \& Ismail, S. (2018). Technological Intensity of Exports of India and China: A Comparative Assessment. Journal of International Economics, 9(2), 50-59.

Baldwin, R. (1993). A Domino Theory of Regionalism. Cambridge, MA: National Bureau of Economic Research, Working Paper 4465, September https://doi.org/10.3386/w4465

Baldwin, R.E. (2006). Multilateralising Regionalism: Spaghetti Bowls as Building Blocs on the Path to Global Free Trade. World Economy, 29(11), 1451-518. https://doi.org/10.1111/j.14679701.2006.00852.x

Baldwin, R. E. (2008). Big-Think Regionalism: A Critical Survey. NBER Working Paper, 14056. https://doi.org/10.3386/w14056 
Is 'WTO-Plus' a Policy Option for India-China Agriculture Trade? A CGE Analysis

Bardhan, P. (1970). Chinese and Indian Agriculture: A Broad Comparison of Recent Policy and Performance. The Journal of Asian Studies, 29(3), 515-537. https://doi.org/10.2307/2943242

Bhagwati, J. (1990). Departures from multilateralism: Regionalism and aggressive unilateralism. The Economic Journal, 100(403), 1304-1317. https://doi.org/10.2307/2233978 Bhagwati, J. (1992). Regionalism versus multilateralism. The World Economy, 15(5), 535-556. https://doi.org/10.1111/i.1467-9701.1992.tb00536.x

Bhattacharya, S.N. \& Bhattacharya B.N. (2007). Gains and Losses of India-China Trade Cooperation: A Gravity model impact analysis. CESifo working paper, No. 1970, https://www.cesifo.org/DocDL/cesifo1 wp1970.pdf

Carter, C. A. (2011). China's Agriculture: Achievements and Challenges. ARE Update, 14(5), 57. University of California Giannini Foundation of Agricultural Economics. https://giannini.ucop.edu/publications/are-update/issues/2011/14/5/chinas-agricultureachiev/

Harrison, W. \& Pearson, K.R. (1996). Computing Solutions for Large General Equilibrium Models Using GEMPACK. Computational Economics, 9, 83-127. https://doi.org/10.1007/BF00123638

Hertel, T. W. \& Tsigas, M. (1997). Structure of GTAP. in Thomas Hertel (ed.) (1997). Global Trade Analysis: Modeling and Applications. Cambridge: Cambridge University Press. https://doi.org/10.1017/CBO9781139174688.003

Hertel, T. W., ed. (1997). Global Trade Analysis: Modeling and Applications. Cambridge: Cambridge University Press.

ICFA (2019). Doubling Agri Exports. https://www.icfa.org.in/agriexport/\#: :text=The\%20share\%20of\%20India's\%20high,losses\%20across\%20the\%20value\%2 Ochain.

Kemp, M. \& Wan, H. Y. Jr. (1976). An Elementary Proposition Concerning the Formation of Customs Unions. Journal of International Economics, 6 (1), 95-98. https://doi.org/10.1016/0022-1996(76)90025-8

Krueger, A. O. (1997). Problems with Overlapping Free Trade Areas. In Regionalism versus Multilateral Trade Arrangements. NBER-EASE, 6, 9-24.

Meade, J. E. (1955). The Theory of Customs Unions. Amsterdam: North-Holland.

Nenci, S. (2011). Tariff Liberalisation and the Growth of World Trade: A Comparative Historical Analysis of the Multilateral Trading System. The World Economy, 34(10), 1809-1835. https://doi.org/10.1111/j.1467-9701.2011.01401.x

Ohyama, M. (1972). Trade and Welfare in General Equilibrium. Keio Economic Studies, 9(2), 37-73.

Panagariya, A. (2000). Preferential trade liberalisation: the traditional theory and new developments. Journal of Economic literature, 38(2), 287-331. https://doi.org/10.1257/jel.38.2.287

Qureshi M. S. \& Wan G. (2008). Trade expansion of China and India: Threat or opportunity? World Economy, 31(10), 1327-1350. https://doi.org/10.1111/j.1467-9701.2008.01131.x

Schott, J. J. (1991). Trading Blocs and the World Trading System. World Economy, 14(1), 1-17. https://doi.org/10.1111/i.1467-9701.1991.tb00748.x 
Sharma, R. (2008). China, India and AFTA: evolving bilateral agricultural trade and new opportunities through free trade agreements. FAO Commodity and Trade Policy Research Working Paper No. 24.

http://www.fao.org/fileadmin/templates/est/PUBLICATIONS/Comm Working Papers/ESCWP24.pdf

Sharma, R., \& Kaur, M. (2013). Causal Links between Foreign Direct Investments and Trade: A Comparative Study of India and China. Eurasian Journal of Business and Economics, 6(11), 7591.

Tai, S. W., \& Lee, J. W. (2019). Strategies of Regional Economic Integration and WTO Accession in Central Asia. Eurasian Journal of Business and Economics, 2(3), 1-14.

USITC (2011). China's Agricultural Trade: Competitive Conditions and Effects on U.S. Exports. Investigation No. 332-518 USITC Publication 4219, March 2011, https://www.usitc.gov/publications/332/pub4219.pdf

Vanek, J. (1965). General Equilibrium of International Discrimination: The Case of Customs Unions. Cambridge: Harvard University Press.

Vásáry, M., Vasa, L., \& Baranyai, Z. (2014). Analysing competitiveness in agro-trade among visegrad countries. Actual Problems of Economics, 151(1), 24-35.

Viner, J. (1950). The Customs Union Issue. New York: Carnegie Endowment for International Peace. 


\section{Appendix-A}

Table A1. Regional Aggregation

\begin{tabular}{|c|c|c|c|}
\hline & New & Region & Comprising \\
\hline No. & Code & Description & old regions \\
\hline 1. & India & India & India. \\
\hline 2. & China & China & China. \\
\hline 3. & ASEAN & Member of ASEAN & $\begin{array}{l}\text { Brunei Darussalam; Cambodia; Indonesia; Lao } \\
\text { People's Democratic Republ; Malaysia; } \\
\text { Philippines; Singapore; Thailand; Viet Nam; Rest } \\
\text { of Southeast Asia. }\end{array}$ \\
\hline 4. & RSouthAsia & Rest of South Asia & $\begin{array}{l}\text { Bangladesh; Nepal; Pakistan; Sri Lanka; Rest of } \\
\text { South Asia. }\end{array}$ \\
\hline 5. & RestofWorld & Rest of World & $\begin{array}{l}\text { Australia; New Zealand; Rest of Oceania; Hong } \\
\text { Kong; Japan; Korea; Mongolia; Taiwan; Rest of } \\
\text { East Asia; Canada; United States of America; } \\
\text { Mexico; Rest of North America; Argentina; } \\
\text { Bolivia; Brazil; Chile; Colombia; Ecuador; } \\
\text { Paraguay; Peru; Uruguay; Venezuela; Rest of } \\
\text { South America; Costa Rica; Guatemala; } \\
\text { Honduras; Nicaragua; Panama; El Salvador; Rest } \\
\text { of Central America; Dominican Republic; } \\
\text { Jamaica; Puerto Rico; Trinidad and Tobago; } \\
\text { Caribbean; Austria; Belgium; Bulgaria; Croatia; } \\
\text { Cyprus; Czech Republic; Denmark; Estonia; } \\
\text { Finland; France; Germany; Greece; Hungary; } \\
\text { Ireland; Italy; Latvia; Lithuania; Luxembourg; } \\
\text { Malta; Netherlands; Poland; Portugal; Romania; } \\
\text { Slovakia; Slovenia; Spain; Sweden; United } \\
\text { Kingdom; Switzerland; Norway; Rest of EFTA; } \\
\text { Albania; Belarus; Russian Federation; Ukraine; } \\
\text { Rest of Eastern Europe; Rest of Europe; } \\
\text { Kazakhstan; Kyrgyzstan; Tajikistan; Rest of } \\
\text { Former Soviet Union; Armenia; Azerbaijan; } \\
\text { Georgia; Bahrain; Iran Islamic Republic of; } \\
\text { Israel; Jordan; Kuwait; Oman; Qatar; Saudi } \\
\text { Arabia; Turkey; United Arab Emirates; Rest of } \\
\text { Western Asia; Egypt; Morocco; Tunisia; Rest of } \\
\text { North Africa; Benin; Burkina Faso; Cameroon; } \\
\text { Cote d'Ivoire; Ghana; Guinea; Nigeria; Senegal; } \\
\text { Togo; Rest of Western Africa; Central Africa; } \\
\text { South Central Africa; Ethiopia; Kenya; } \\
\text { Madagascar; Malawi; Mauritius; Mozambique; } \\
\text { Rwanda; Tanzania; Uganda; Zambia; Zimbabwe; } \\
\text { Rest of Eastern Africa; Botswana; Namibia; } \\
\text { South Africa; Rest of South African Customs ; } \\
\text { Rest of the World. }\end{array}$ \\
\hline
\end{tabular}


Shahid AHMED \& Saba ISMAIL

Table A2. Sectoral Aggregation

\begin{tabular}{|c|c|c|c|}
\hline & New & Sector & Comprising \\
\hline No. & Code & Description & old sectors \\
\hline 1. & Agr & Agriculture Sector & $\begin{array}{l}\text { Paddy rice; Wheat; Cereal grains nec; } \\
\text { Vegetables, fruit, nuts; Oil seeds; Sugar cane, } \\
\text { sugar beet; Plant-based fibers; Crops nec; } \\
\text { Bovine cattle, sheep and goats; Animal } \\
\text { products nec; Raw milk; Wool, silk-worm } \\
\text { cocoons; Forestry; Fishing; Bovine meat } \\
\text { products; Meat products nec; Vegetable oils } \\
\text { and fats; Dairy products; Processed rice; } \\
\text { Sugar; Food products nec; Beverages and } \\
\text { tobacco products. }\end{array}$ \\
\hline 2. & Mnfc & Manufacturing Sector & $\begin{array}{l}\text { Coal; Oil; Gas; Minerals nec; Textiles; Wearing } \\
\text { apparel; Leather products; Wood products; } \\
\text { Paper products, publishing; Petroleum, coal } \\
\text { products; Chemical products; Basic } \\
\text { pharmaceutical products; Rubber and plastic } \\
\text { products; Mineral products nec; Ferrous } \\
\text { metals; Metals nec; Metal products; } \\
\text { Computer, electronic and optic; Electrical } \\
\text { equipment; Machinery and equipment nec; } \\
\text { Motor vehicles and parts; Transport } \\
\text { equipment nec; Manufactures nec. }\end{array}$ \\
\hline 3. & Services & Service Sector & $\begin{array}{l}\text { Electricity; Gas manufacture, distribution; } \\
\text { Water; Construction; Trade; Accommodation, } \\
\text { Food and services; Transport nec; Water } \\
\text { transport; Air transport; Warehousing and } \\
\text { support activities; Communication; Financial } \\
\text { services nec; Insurance; Real estate activities; } \\
\text { Business services nec; Recreational and other } \\
\text { service; Public Administration and defence; } \\
\text { Education; Human health and social work; } \\
\text { Dwellings. }\end{array}$ \\
\hline
\end{tabular}

